\title{
FUNCTIONING PITUITARY TUMOURS: A CLINICOBIOCHEMICAL CORRELATION
}

\section{Parna Chakraborty}

\section{Parthasarathi} Datta*
Senior Resident, Department Of Biochemistry, College Of Medicine And Sagore Dutta Hospital, Kolkata, Westbengal, India.

Associate Professor, Department of Neurosurgery, NRS Medical College, Kolkata, Westbengal, India. ${ }^{*}$ Corresponding Author

ABSTRACT

Introduction: Pituitary tumours may be functioning or non-functioning. Functioning tumours secrete PRL, $\mathrm{GH}, \mathrm{ACTH}, \mathrm{TSH}, \mathrm{FSH}, \mathrm{LH}$ and have clinical features pertaining to the hormones. We in our study tried to analyze the pre-op and post-op clinicoendocrinological (biochemical) status.

Materials And Methods: Over a span of 10 years from Jan 2010 to Jan 2020 we studied the pre-op and post-op clinical features, radiology (CT, MRI) and endocrine levels of 20 patients with functioning pituitary adenomas.

Results: Completeness of tumour removal dictates normalization of clinical features and endocrine levels. Microadenomas pose a more remission rate than macroadenomas.

Conclusion: Total tumour removal in a functioning pituitary adenoma normalizes the clinicoendocrinological parameters. Normalization rates are far more for microadenomas than macroadenomas.

\section{KEYWORDS : Pituitary, adenohypophysis, somatotrophs, lactotrophs, corticotrophs}

\section{INTRODUCTION}

Pituitary tumours constitute a unique class of neoplasia.

The most important is endocrine concerns and oncological issues. The diagnostic and therapeutic concerns reflect the duality of this clinical problem. Schloffer ( 1868-1939) first employed lateral rhinotomy to approach Sella.

Technical contributions by Heurer( 1882-1950) Frazier(18701936),Krause( 1857-1937) Cushing and others led to adoption of transcranial approaches of pituitary .Norman Dott ( 18971973) of Edinburgh,Gerard Guiot ( 1912-1996) of France ${ }^{2}$ and Jules Hardy of Montreal ${ }^{3}$ popularized the transsphenoidal microsurgery which is the preferred approach for more than $95 \%$ of pituitary tumours.

Pituitary tumours account for $10-15 \%$ of all primary brain tumours. ${ }^{4}$ Most pituitary tumours originate within the adenohypophysis. Adenohypophysis includes pars distalis ( anterior lobe), pars intermedia( intermediate lobe) and pars tuberalis .The anterior lobe is composed of five principal secretory cell types somatotrophs (growth hormone secretion $\mathrm{GH})$, lactotrophs( prolactin secretion PRL), corticotrophs ( adrenocorticotrophic hormone secretion ACTH secretion), thyrotrophs( thyroid stimulating hormone TSH secretion) and gonadotrophs ( luteinizing hormone LH and follicle stimulating hormone FSH secretion ).Among the functioning pituitary tumours the common are Prolactinoma( $30 \%$ of all pituitary tumours), somatotroph adenoma, corticotroph adenoma, thyrotroph pituitary adenoma( $<1 \%$ of all pituitary tumours) $)^{5,6}$.

We in our study analyzed the clinical features and endocrine status ( biochemical parameters) of patients before and after operation.

\section{MATERIALS AND METHODS:}

Over a span of 10 years (from Jan 2010 to Jan 2020 ) we followed 20 patients of functioning pituitary adenoma.We studied their clinical features and endocrine levels and tried to analyze the improvement of clinical features and normalization of endocrine levels after operation.

After patient admission the work up of the patients which was done are:

Clinical Manifestations :

a. Pituitary hyperfunction

\section{b. Pituitary insufficiency}

c. Mass effect

Establish Ann Endocrine Diagnosis :

PRL, GH, ACTH, LH, FSH, TSH, thyroxine, IGF-1(insulin like growth factor type 1).

Establish an anatomical diagnosis :

a. Conned-down view of sella xray

b. CT paranasal sinuses

c. MRI brain seller view ( plain + contrast).

\section{Optional}

Automated perimetry, visual evoked potential, four vessel DSA/CT Angiogram Brain

All the patients $(n=20)$ of functioning pituitary adenoma were operated by microscopic sublabial transseptal transsphenoidal approach or Endoscopic transsphenoidal approach. Postoperatively clinical features, endocrine levels and MRI were repeated at 6 weeks, 6 months and 1 year.

We tried to correlate resolution of clinical features and endocrine levels with the extent of tumour removal.

Prolactinoma $(n=10)$

\begin{tabular}{|c|c|c|c|c|c|c|}
\hline Size & $\begin{array}{l}\text { Extensi } \\
\text { on }\end{array}$ & \begin{tabular}{|l|} 
Extent \\
of \\
tumour \\
removal
\end{tabular} & $\begin{array}{l}\text { Clini } \\
\text { cal } \\
\text { featu } \\
\text { res } \\
\text { Pre- } \\
\text { op }\end{array}$ & \begin{tabular}{|l|} 
Clinical \\
feature \\
s \\
Post-op
\end{tabular} & \begin{tabular}{|l|} 
Endoc \\
rine \\
levels \\
Pre-op
\end{tabular} & $\begin{array}{l}\text { Endocr } \\
\text { ine } \\
\text { levels } \\
\text { Postop }\end{array}$ \\
\hline \begin{tabular}{|l|} 
Microade \\
noma l
\end{tabular} & - & $\begin{array}{l}\text { Complet } \\
\text { e }\end{array}$ & $\begin{array}{l}\text { Flori } \\
\mathrm{d}\end{array}$ & \begin{tabular}{|l|} 
Resolve \\
d
\end{tabular} & $\uparrow \uparrow \uparrow \uparrow$ & No \\
\hline $\begin{array}{l}\text { Macroade } \\
\text { noma } 9\end{array}$ & $\begin{array}{l}\text { Supra \& } \\
\text { parasell } \\
\text { ar }\end{array}$ & \begin{tabular}{|l} 
Complet \\
e -5 \\
Incompl \\
ete-4
\end{tabular} & " & $\begin{array}{l}\text { Partial } \\
\text { resoluti } \\
\text { on }\end{array}$ & $\begin{array}{l}\uparrow \uparrow \uparrow \\
\uparrow \uparrow \uparrow\end{array}$ & $\begin{array}{l}\text { Norm } \\
\uparrow\end{array}$ \\
\hline
\end{tabular}

GH Secreting Adenoma ( $\mathrm{n}=8$ )

\begin{tabular}{|c|c|c|c|c|c|c|}
\hline Size & $\begin{array}{l}\text { Extensi } \\
\text { on }\end{array}$ & \begin{tabular}{|l|} 
Extent \\
of \\
tumour \\
remova \\
1
\end{tabular} & $\begin{array}{l}\text { Clini } \\
\text { cal } \\
\text { featu } \\
\text { res } \\
\text { Pre- } \\
\text { op }\end{array}$ & $\begin{array}{l}\text { Clinic } \\
\text { al } \\
\text { featur } \\
\text { es } \\
\text { post- } \\
\text { op }\end{array}$ & \begin{tabular}{|l|} 
Endocr \\
ine \\
levels \\
pre-op
\end{tabular} & \begin{tabular}{|l|} 
Endocr \\
ine \\
levels \\
post- \\
op
\end{tabular} \\
\hline \begin{tabular}{|l|} 
Microadeno \\
ma 2
\end{tabular} & - & \begin{tabular}{|l|} 
Comple \\
te
\end{tabular} & $\begin{array}{l}\text { Flori } \\
\text { d }\end{array}$ & $\begin{array}{l}\text { Resolv } \\
\text { ed }\end{array}$ & 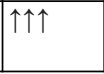 & Normal \\
\hline
\end{tabular}




\begin{tabular}{|c|c|c|c|c|c|c|}
\hline $\begin{array}{l}\text { Macroaden } \\
\text { oma } 6\end{array}$ & $\begin{array}{l}\text { Supras } \\
\text { ellar \& } \\
\text { parasel } \\
\text { lar }\end{array}$ & \begin{tabular}{|l|} 
Comple \\
te-3 \\
Incompl \\
ete -3
\end{tabular} & " & \begin{tabular}{|l} 
Resolv \\
ed \\
Partial \\
resolut \\
ion
\end{tabular} & $\begin{array}{l}\uparrow \uparrow \uparrow \\
\uparrow \uparrow \uparrow\end{array}$ & Normal \\
\hline
\end{tabular}

Corticotroph Adenoma

\begin{tabular}{|c|c|c|c|c|c|c|}
\hline Size & \begin{tabular}{|l|} 
Extens \\
ion
\end{tabular} & $\begin{array}{l}\text { Extent } \\
\text { of } \\
\text { tumour } \\
\text { remov } \\
\text { al }\end{array}$ & \begin{tabular}{|l|} 
Clini \\
cal \\
featu \\
res \\
pre- \\
op \\
\end{tabular} & \begin{tabular}{|l} 
Clinic \\
al \\
featur \\
es \\
Post \\
op \\
\end{tabular} & \begin{tabular}{|l|} 
Endocr \\
ine \\
levels \\
pre-op
\end{tabular} & \begin{tabular}{|l|} 
Endocr \\
ine \\
Levels \\
post-op
\end{tabular} \\
\hline $\begin{array}{l}\text { Microadeno } \\
\text { ma } 2\end{array}$ & - & $\begin{array}{l}\text { Compl } \\
\text { ete }\end{array}$ & Florid & $\begin{array}{l}\text { Resolv } \\
\text { ed }\end{array}$ & $\uparrow \uparrow \uparrow$ & Normal \\
\hline
\end{tabular}

\section{RESULTS:}

From our study we came to the opinion that complete tumour removal leads to resolution of clinical features and normalization of serum endocrine levels and incomplete removal leads to partial resolution of clinical features and reduction ( not normalization) of endocrine levels.

Among 10 patients of Prolactinoma in one microadenoma and five macroadenomas we achieved complete tumour removal leading to complete resolution of clinical features and normalization of endocrine levels. In other adenomas our result was suboptimal.

Among 8 patients of GH secreting adenomas in 2 microadenomas and 3 macroadenomas we achieved complete tumour removal leading to complete resolution of clinical features and normalization of endocrine levels. In other cases our result was suboptimal.

Among 2 corticotroph microadenomas we achieved complete tumour removal in both leading to complete resolution of clinical features and normalization of endocrine levels.

\section{DISCUSSION :}

Pituitary adenomas generally present with features of hypersecretion (hyperfunction) ,hypofunction and mass effect ${ }^{7}$. Features of hyperfunction of prolactinomas in female are amenorrhoea-galactorrhea syndrome. And in males produces hypogonadism leading to reduced libido, impotence and relative infertility. Normal PRL level is $3-20 \mathrm{ng} /$ $\mathrm{ml}$. Values between $50-200 \mathrm{ng} / \mathrm{ml}$ indicates small prolactinoma, pseudo prolactinoma or stalk-section effect. Level > $200 \mathrm{ng} / \mathrm{ml}$ indicate pure prolactinoma. And level > $1000 \mathrm{ng} / \mathrm{ml}$ indicates' invasive prolactinoma'.

Hyperfunction of GH causes gigantism( before epiphyseal closure) and acromegaly (after puberty). Facial features become coarse,thickened lips, frontal bossing, prognathism ,dental malocclusion, resonant voice, macroglossia, spade like hands and feet, increased heel pad thickness, malodorous perspiration, barrel shaped chest. Normal GH level is $1-5 \mathrm{ng} / \mathrm{ml}$. Endocrine criteria for GH adenoma is elevated basal GH level > $5 \mathrm{ng} / \mathrm{ml}$, insufficient $\mathrm{GH}$ suppressibility ( $>2 \mathrm{ng} / \mathrm{ml}$ ) on oral glucose tolerance testing and elevation of serum IGF -1 levels. GH excess may occur in extra pituitary GH releasing hormone (GHRH) producing tumour.

Corticotroph adenomas secrete $\mathrm{ACTH}$ and thus produce a hypercortisolemic state.Cushing's disease is those hypercortisolemic state in response to an ACTH secreting pituitary tumour. Cushing's syndrome is any pathological or iatrogenic state of glucorticoid excess. Clinical features are weight gain with centripetal fat deposition, skin changes in the form of thinning, easy bruising, plethoric appearance, purple stria over the abdomen, hirsutism, hyperpigmentation(rare).
Hypertension, glucose intolerance, osteoporosis, steroid myopathy, menstrual dysfunction in female, decreased libido and infertility in male,impaired host defenses, psychiatric disturbances in the form of depressed mood, emotional lability, mania, psychosis also occur. ACTH normal range is 6$76 \mathrm{pg} / \mathrm{ml}$. Cortisol normal range is $6-23 \mathrm{ug} / \mathrm{dl}$.

The Standard Protocol For Hypercortisolemia Diagnosis :

a. Measurement of free 24 hour urinary cortisol, low dose dexamethasone suppression test, overnight dexamethasone suppression test.

b. Measurement of plasma ACTH level.

c. High dose dexamethasone suppression test

d. Bilateral inferior petrosal sinus sampling

\section{Features Of Hypofunction:}

Due to chronic compression, cells are affected in the following sequence: Gonadotrophs $\rightarrow$,thyrotrophs $\rightarrow$, somatotrophs, $\rightarrow$ corticotrophs. Posterior pituitary failure occurs rarely ${ }^{8}$.

Features of mass effect : Headache, visual loss, hypothalamus dysfunction, hydrocephalus (third ventricle compression), cavernous sinus involvement causes cranial nerve involvement, mesial temporal lobe involvement causes complex partial seizures.

All our tumours were operated and managed by the same team of neurosurgeons, neuroanaesthetists, endocrinologists and biochemists. After operation evaluation of the patients were done at 6 weeks, 6 months and 1 year by clinical examination, radiology ( MRI sellar region) and endocrinological examination. In our series completeness of tumour removal resulted in normalization of clinical features and endocrine levels whereas incomplete tumour removal resulted in partial remission of symptoms and endocrine levels. Also the remission rate were more for microadenomas than macroadenomas. Various other series like Fahlbusch et al 9 also reported similar results like remission rates were more for microadenomas than macroadenomas.

\section{CONCLUSION :}

For the functioning pituitary tumours remission of clinical features and endocrine levels are more with completeness of tumour removal. Also microadenomas showed a more remission than macroadenomas.

\section{REFERENCES :}

1. Schloffer H:Erfolgreiche Operation eines Hypophysentumors auf nasalem Wege.Wien Klin Wochenschr 1907;20:621-624

2. Guiot G,Arfel G,Brion S,et al:Adenomes hypophysaires.Paris,Masson, 1958:p276.

3. Hardy J:Transsphenoidal surgery of the normal and ppathological pituitary.Clin Neurosurg. 1969:16;185-217.

4. Kovacs K,Horvath E.Tumors of the pituitary gland.Atlas of Tumor pathology,fascicle 21,2nd series .Washington DC,Armed Forces Institute of Pathology.1986; 1-269.

5. Thaper K,Kovacs K.Tumors of the sellar region In Bigner DD,McLendon RE,Bruner JM(eds).Russel and Rubinstein's Pathology of tumors of the Nervous System.Baltimore, Williams \& Wilkins. 1998:561-677.

6. Thapar K,Kovacs K, Laws ER .The classification and molecular biology of pituitary adenomas.Adv Tech Stand Neurosurg. 1995: 22;3-53.

7. Kovacs K,Scheithauer B,Horvath E,Lloyd R.The World Health Organisation classification of adenohypophyseal neoplasms.A proposed five-tier scheme.Cancer 1996;78:502-510.

8. Thapar K, Scheithauer B,Kovacs K, et al.Assessment of mitotic activity in pituitary adenomas and carcinomas.Endocr Pathol 1996;7:215-222.

9. Fahlbusch R,Honegger J,Buchfelder M.Surgical management of acromegaly.Endocrinol Metab Clin North Am 1992;21:669-692. 